DOI https://doi.org/10.15589/znp2019.4(478).2

УДК 339.137.2

\title{
MANAGING THE COMPETITIVENESS OF FOOD ENTERPRISES THROUGH THE DEVELOPMENT OF COMPETITIVE ADVANTAGES
}

\section{УПРАВЛІННЯ КОНКУРЕНТОСПРОМОЖНІСТЮ ПІДПРИЄМСТВ ХАРЧОВОЇ ПРОМИСЛОВОСТІ ШЛЯХОМ РОЗВИТКУ КОНКУРЕНТНИХ ПЕРЕВАГ}

\author{
Antonina S. Zienina-Bilichenko \\ А. С. Зсніна-Біліченко, \\ t.bilichenko@gmail.com \\ ORCID: 0000-0001-6147-2827 \\ канд. екон. наук, доцент
}

National University of Food Technologies, Kyiv, Ukraine
Національний університет харчових технологій, м. Київ

\begin{abstract}
The problems of determining the competitiveness of the products of enterprises, methods of its diagnostics, as well as scientific and practical recommendations on organizational support are investigated. The impact of increasing the level of competition in the domestic and foreign markets, increasing consumer demand on the opportunities for development and prosperity of the enterprise, which will have competitive advantages in all areas, including in the area of cost reduction, quality improvement, flexibility, innovation, knowledge development and in the field of economy time. Identification of sources of formation of competitive advantages of Ukrainian food industry enterprises is also investigated. It is determined that competitive advantage is a concentrated manifestation of superiority over competitors in the economic, technical and organizational spheres of the enterprise, which can be measured by economic indicators (additional profit, higher profitability, market share, sales volume). It should be emphasized that the competitive advantage cannot be equated with the potential of the company. Assessment and systematic determination of competitive advantages, sources of their formation due to the calculation of the main indicators for valuation in the enterprise, which was selected for in-depth study. It is determined that the most common causes of innovations that give a competitive advantage are: new technologies; new or changing consumer requests; change in the cost or availability of production components; the emergence of a new segment of the industry; change in government regulation. The study of competitiveness is a component of the analysis of the market of competitors, determination of the mechanism of its functioning. Effective implementation of such an analysis requires detailed information about the company, the competitive situation, market factors and the results of their action. The competitiveness of the enterprise is an independent system category, which reflects the degree of realization of the purpose of the enterprise in its interaction with the environment. The relevance of such research and management of this category increases with the formation of market relations and reform of the competitive environment. Due to the analysis, practical recommendations for improving the competitive advantage formation were developed. The factors that provide the ability to compete in the meat market that identify ways to increase the competitiveness of the enterprise are identified. The feasibility of the proposed measures is substantiated.
\end{abstract}

Key words: competitiveness of enterprises; competitive advantage; monitoring; consumer; products.

Анотація. Досліджено питання щодо визначення конкурентоспроможності продукції підприємств, методів ії діагностики, а також науково-практичних рекомендацій щодо організаційного забезпечення. Проаналізовано вплив підвищення рівня конкуренції на внутрішньому і зовнішніх ринках, зростання вимогливості споживачів на можливості розвитку та процвітання підприємства, що матиме конкурентні переваги в усіх сферах, зокрема у сфері зниження витрат, покращання якості, забезпечення гнучкості, упровадження інновацій, розвитку знань і у сфері економії часу. Також досліджено визначення джерел формування конкурентних переваг українських підприємств харчової промисловості. Визначено, що конкурентні переваги є концентрованим проявом переваги над конкурентами в економічній, технічній, організаційній сферах діяльності підприємства, які можна виміряти економічними показниками (додатковий прибуток, більш висока рентабельність, ринкова частка, обсяг продаж). Необхідно особливо підкреслити, що конкурентну перевагу не можна ототожнювати з потенційними можливостями компанії. Надано оцінку та систематизовано визначення конкурентних переваг, джерела їх формування завдяки розрахунку основних показників щодо оцінки на підприємстві, що було вибране для поглибленого вивчення. Визначено, що найбільш типовими причинами новацій, що дають конкурентну перевагу, виступають: нові технології; нові або такі, що змінюються, запити споживачів; зміна вартості або наявності компонентів виробництва; поява нового сегмента галузі; зміна урядового регулювання. Дослідження конкурентоспроможності є складовою частиною аналізу ринку конкурентів, визначення механізму його 
функціонування. Для ефективного здійснення такого аналізу необхідна детальна інформація про підприємство, конкурентну ситуацію, ринкові чинники та результати їхньої дії. Конкурентоспроможність підприємства становить самостійну системну категорію, яка відображає ступінь реалізації мети підприємства в його взаємодії з навколишнім середовищем. Актуальність такого дослідження й управління цією категорією зростає 3 формуванням ринкових відносин і реформуванням конкурентного середовища. Завдяки проведеному аналізу розроблено практичні рекомендації щодо вдосконалення формування конкурентних переваг. Визначено чинники, що забезпечують здатність конкурувати на ринку м'ясної галузі, що дозволяють знайти шляхи підвищення конкурентоспроможності підприємства. Обгрунтовано доцільність запропонованих заходів.

Ключові слова: конкурентоспроможність підприємств; конкурентна перевага; моніторинг; споживач; продукція.

\section{ПОСТАНОВКА ЗАДАЧІ}

Проблема забезпечення конкурентоспроможності продукції українських підприємств харчової галузі $€$ однією з найбільш актуальних проблем, що потребує розроблення чітких принципів оцінки й управління, від яких залежить ефективне функціонування вітчизняної економіки. Конкурентоспроможність підприємства є однією з найважливіших категорій ринкової економіки і характеризує можливість та ефективність адаптації підприємства до умов конкурентного середовища. У зв'язку із цим обгрунтування підходів до iii дослідження з метою наступної розробки системи заходів для зміцнення позиції та досягнення конкурентних переваг підприємства є актуальним. Ключовими в економіці України є харчові підприємства. Це зумовлено тим значенням, яке має харчова галузь у структурі національної економіки. Створення стійких конкурентних позицій економіки України передбачає підвищення рівня конкурентоспроможності виробників. Вітчизняні підприємства повинні зосереджувати увагу не тільки на ефективності виробництва, але й на ефективності функціонування в конкурентному середовищі, а тому виникає необхідність науково-методичного забезпечення оцінки та діагностики їхньої конкурентоспроможності.

Тому проблеми підвищення конкурентоспроможності харчових підприємств на внутрішньому і міжнародних ринках важливі як у сучасних умовах, так i в майбутньому, що актуалізує тему дослідження.

\section{АНАЛІЗ ОСТАННІХ ДОСЛІДЖЕНЬ І ПУБЛІКАЦЙ}

У сучасній економічній науці дуже багато наукових праць присвячено проблемі конкурентоспроможності підприємства, конкурентним перевагам суб'єктів ринку, важливості формування ефективної конкурентної стратегії організації. Найбільш помітний внесок у сучасну теорію конкуренції та дослідження понять, пов'язаних із конкурентоспроможністю, зробив М. Портер. Аналіз конкуренції та конкурентоспроможності підприємства також проводили у своїх працях такі іноземні та вітчизняні вчені, як: Ж.-Ж. Ламбен, П. Дойль, Р. Уенслі, Ф. Котлер, Р. Фатхутдінов, Г. Азоєв, В. Білошапка, Г. Михайлик, О. Герман, Л. Піддубна, О. Юданов.

\section{ВІДОКРЕМЛЕННЯ НЕВИРІШЕНИХ РАНІШЕ ЧАСТИН ЗАГАЛЬНОЇ ПРОБЛЕМИ}

Для досліджуваного підприємства важливий розгляд конкурентних переваг із позиції споживача та розроблення практичних рекомендацій щодо формування стійкої конкурентної позиції на внутрішньому і міжнародних ринках як у сучасних умовах, так і в майбутньому.

Мета дослідження полягає в науковому обгрунтуванні нових концептуальних засад забезпечення конкурентоспроможності підприємств і розроблення на його основі методичних положень і практичних рекомендацій, спрямованих на досягнення та збереження стійких конкурентних позицій підприємства завдяки певним маркетинговим орієнтаціям у динамічних умовах макроекономічного середовища.

\section{МЕТОДИ, ОБ'СКТ ТА ПРЕДМЕТ ДОСЛІДЖЕННЯ}

Основу теоретико-методичних розробок становлять результати наукових пошуків вітчизняних і закордонних учених, фундаментальні положення економічної теорії та загальнонаукової методології. Під час проведення дослідження застосовувалися такі методи: системного аналізу - для дослідження формування економічних відносин на ринку м'ясної продукції; порівняння - для виявлення впливу окремих чинників на конкурентоспроможність підприємств; абстрактно-логічний - для визначення ролі економічних відносин в оцінюванні рівня конкурентоспроможності підприємств; кореляційно-регресійного аналізу - для проведення комплексного оцінювання конкурентоспроможності підприємств. Об'єктом дослідження є процес забезпечення конкурентоспроможності продукції підприємства ТДВ «Конотопм’ясо». Предмет досліджень - комплекс теоретичних, методичних і практичних аспектів забезпечення конкурентоспроможності продукції підприємства.

\section{ОСНОВНИЙ МАТЕРІАЛ}

Поступовий розвиток ринкових відносин в Україні зумовлює надання конкурентоспроможності значення ключового чинника успішної діяльності суб'єктів вітчизняного ринку. Це значення зумовлене підвищенням інтересу до стратегічних питань бізнесу, а також до підходів і методів їх вирішення, які полягають у 
зосередженні зусиль значної кількості підприємств на налагодженні виробництва конкурентоспроможної продукції, а також у вивченні досвіду іноземних компаній, які постачають на ринок продукцію, кращу за своїми параметрами порівняно з вітчизняною, з метою його використання на своєму підприємстві [1, с. 87].

Загалом, у механізмі ринкової взаємодії конкуренція виконує роль основної рушійної сили розширеного відтворення й ефективної самоорганізації, змушуючи виробників продукції підвищувати іiї якість, знижувати витрати на виробництво, підвищувати продуктивність праці, шукати інноваційні напрями забезпечення унікальності продукту [2, с. 60]. Проте за умови підвищення інтеграції ринкових відносин не тільки конкурентоспроможність продукції впливає на конкурентоспроможність підприємства. Високий ступінь задоволення формує не тільки раціональну перевагу, а й емоційну прихильність до конкретної марки товару.

Одна з умов повного задоволення споживача полягає у формуванні в компанії високої поведінкової культури, коли мета кожного працівника - задовольнити покупця.

Існують такі механізми виміру ступеня задоволення споживача:

- система збору скарг і пропозицій;

- опитування про ступінь задоволення споживачів;

- покупці-невидимки;

- аналіз причин скорочення кількості клієнтів.

Аналіз літератури, присвяченої проблемам конкурентоспроможності підприємств, показує, що існує кілька підходів до визначення сутності конкурентних переваг. Досить поширене визначення конкурентних переваг як тих характеристик, споживчих властивостей товару або марки, які створюють для фірми певну перевагу над іiі безпосередніми конкурентами. Така перевага досягається через надання споживачам більших благ: завдяки або реалізації дешевшої продукції, або пропозиції високоякісних продуктів із набором до- даткових послуг, проте за порівняно вищими цінами $[3$, с. 45$]$.

Даний підхід розглядає конкурентні переваги здебільшого з позиції споживачів. Його недолік полягає в обмеженості чинників, які можуть бути визнаними як конкурентні переваги. Так, наприклад, найнижчі питомі витрати, які не відображені в ціні товару (коли підприємство витрачає на виробництво та реалізацію товарів менше, ніж інші фірми галузі, а ціну тримає на середньогалузевому рівні внаслідок загрози цінової війни або інших чинників), дають підприємству суттєві переваги над конкурентами. У цій ситуації підприємство з кожної проданої одиниці товару отримує більше прибутку, який може бути спрямований на оновлення продукції, модернізацію виробництва, пошук і впровадження різноманітних інновацій i, зрештою, на подальше зростання продуктивності та закріплення конкурентної позиції на ринку.

Зміцнення конкурентоспроможності підприємства потрібно розглядати як довготерміновий послідовний процес пошуку й реалізації управлінських рішень у всіх сферах його діяльності, здійснюваний системно, відповідно до обраної стратегії довготермінового розвитку, з урахуванням змін у зовнішньому оточенні та стану засобів самого підприємства, внесенням відповідних коректив [4, с. 56].

Головні завдання вирішення проблеми підвищення конкурентоспроможності підприємства такі:

- визначення критеріїв конкурентоспроможності й формування системи показників її вимірювання;

- розроблення методів оцінки рівня конкурентоспроможності;

- розроблення методів формування алгоритмів (програм) підвищення конкурентоспроможності.

Водночас конкурентна стратегія, яка спрямована на зміцнення конкурентної позиції підприємства, повинна передбачати заходи, що представлені на рис. 1.

\begin{tabular}{|c|c|c|}
\hline \multirow{5}{*}{$\begin{array}{l}\text { Зміцнення } \\
\text { конкурентної } \\
\text { позиції } \\
\text { підприємства }\end{array}$} & \multirow{3}{*}{$\begin{array}{l}\text { Формування ефективної } \\
\text { конкурентної стратегії }\end{array}$} & 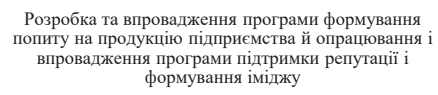 \\
\hline & & $\begin{array}{c}\text { Впровадження передового світового досвіду з } \\
\text { організациї виробництва та зоууту й вдосконалененя } \\
\text { систем розрахункків за подуккціо }\end{array}$ \\
\hline & & 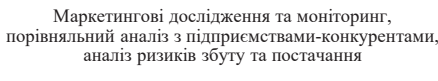 \\
\hline & $\begin{array}{c}\text { Формування ефективних } \\
\text { факторів виробництва та } \\
\text { підвищення ефективності }\end{array}$ & $\begin{array}{l}\text { Забезпечення постійного технологічного оновлення } \\
\text { виробнництва й підвищения якості та дизайну } \\
\text { продукциї }\end{array}$ \\
\hline & $\begin{array}{c}\text { використання ресурсів } \\
\text { підприємства }\end{array}$ & $\begin{array}{l}\text { Розробкка заходів, спрямованих на забезпечення та } \\
\text { свосчасності стабільності постачань матеріальних } \\
\text { ресурсів необхідної якості та обсягіi }\end{array}$ \\
\hline
\end{tabular}

Рис. 1. Заходи щодо зміцнення конкурентних позицій підприємств у сучасних умовах 
Розвиток відносин між бізнес-партнерами вимагає застосування щораз складніших методів управління: від операційного управління (на рівні разових трансакцій) до стратегічного управління (на рівні партнерських відносин, інтеграціi). Чим складніші i триваліші відносини, тим більший потенціал формування стійкої конкурентної переваги через унікальність сформованих відносин і спектр можливостей їх реалізації.

Довговічність конкурентної переваги залежить від швидкості, з якою знецінюються чи застарівають ті ресурси і здібності, на яких вона побудована, причому здібності суб' єкта господарювання більш довговічні, ніж його ресурси, оскільки підприємство може підтримувати їх шляхом заміни чи оновлення ресурсів. Зрозумілість переваги пов'язана з можливістю конкурентів виявити здібності, що лежать в основі конкурентної переваги, визначити ресурси, які необхідні для набуття таких здібностей, та використовувати їх.

Отже, з метою формування міцних конкурентних позицій підприємств варто здійснювати моніторинг конкурентного середовища з метою своєчасного виявлення і прогнозування тенденцій розвитку конкурентних ситуацій, що впливають на конкурентну позицію суб'єкта, проводити оцінку його конкурентних переваг, формувати і реалізовувати ефективні конкурентні стратегії.
Оскільки рівень конкурентоспроможності м'ясопереробного підприємства значною мірою визначається конкурентними перевагами, то для підвищення конкурентоспроможності необхідно підвищити рівень потенціалу підприємства на функціональних напрямках діяльності - виробничому, маркетинговому, інноваційному, фінансовому тощо.

Для визначення слабких і сильних сторін у діяльності підприємства, можливостей і загроз, а також впливу внутрішніх і зовнішніх чинників на формування конкурентоспроможного рівня можна використовувати матричні методи оцінки конкурентоспроможності, а саме SWOT-аналіз. Характеристика отриманих результатів дозволяє дійти висновків, що ТДВ «Конотопм'ясо» має значну кількість проблем, які потребують дослідження й усунення. Наприклад, керівництво підприємства не використовує сучасні методи управління, не впроваджує інновації у виробництво (рис. 2).

Усі розглянуті чинники істотно впливають на формування стратегічного набору (формування корпоративних стратегій і стратегій на рівні виробничого підрозділу) на основі визначення місії, цілей підприємства, зовнішніх та внутрішніх чинників впливу. Після того як визначена загальна ідея розвитку підприємства, можна побудувати функціональні стратегії реалізації загальної ідеї, деталізувати рішення за функціональними напрямами, як-от: виробництво,
Використання сильних ринкових позицій на рівні регіону виробника підприємство може розширити мережу збуту продукції, обслуговувати додаткові групи споживачів; маючи диференціацію виробів та високу якість м'ясних виробів підприємство має змогу залучити інвестиційний капітал та захоплювати нові ринки.
Можливості розширення асортименту та залучення інвестиційного капіталу, ПАТ

«Конотопм'ясо» долає загрозу вузького асортименту, а також відсутність реклами.

Керівництво розробляє стратегію забезпечення конкурентоспроможності продукції та задовольняє смаки споживачів.

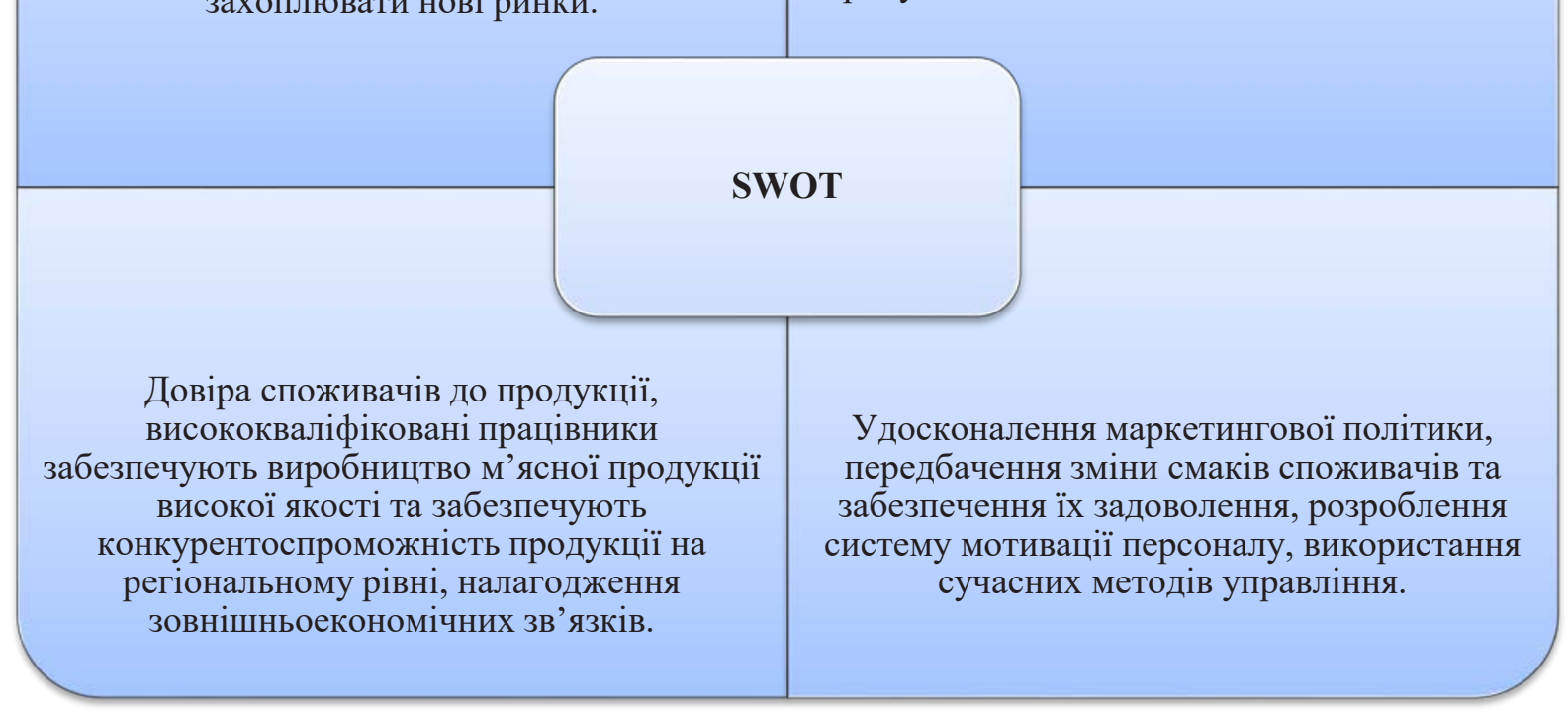

Рис. 2. Матриця SWOT для ТДВ «Конотопм'ясо» 
фінанси, маркетинг, кадри, організаційна культура, довести до кожного функціонального керівника. Кожний 3 елементів впливає на діяльність підприємства, відкриваючи нові можливості поліпшення фінансового й економічного стану, а також на імідж і соціальній статус підприємства в очах працівників та споживачів, дозволяє збільшити обсяги виробництва, забезпечувати новими робочими місцями і збільшувати прибутки.

Отже, до можливих заходів підвищення конкурентоспроможності продукції ТДВ «Конотопм'ясо» можна віднести такі (рис. 3).

Отже, розглянувши зв'язок конкурентоспроможності продукції та підприємства, а також чинники, що забезпечують здатність конкурувати на ринку м'ясної галузі, шляхи покращення, можна зробити висновок про можливості підприємства ефективно використовувати виробничий потенціал та претендувати на завоювання більшого кола споживачів. Досліджуване підприємство значно менше за лідерів ринку, проте не тільки забезпечує продукцією регіон, а й імпортує іiі за кордон.

\section{ОБГОВОРЕННЯ ОТРИМАНИХ РЕЗУЛЬТАТІВ}

Зовнішні та внутрішні конкурентні переваги, що взаємодіють одна з одною, створюють загальні конкурентні переваги, що дають можливість підприємству втілювати обрану стратегію управління та виробництва, вдало функціонувати в конкурентному середовищі, формуючи тим самим свою конкурентоспроможність. Так, зовнішні конкурентні переваги, з одного боку, орієнтують підприємство на розвиток і використання внутрішніх переваг, а з іншого - забезпечують йому стійкі конкурентні позиції, оскільки орієнтують на цілеспрямоване задоволення потреб конкретної групи споживачів. Отже, конкурентні переваги посідають важливе місце у формуванні та забезпеченні конкурентоспроможності підприємства, є запорукою його стійкої конкурентної позиції, визначають напрям формування конкурентної стратегії підприємства, беруть участь у становленні конкурентного потенціалу.

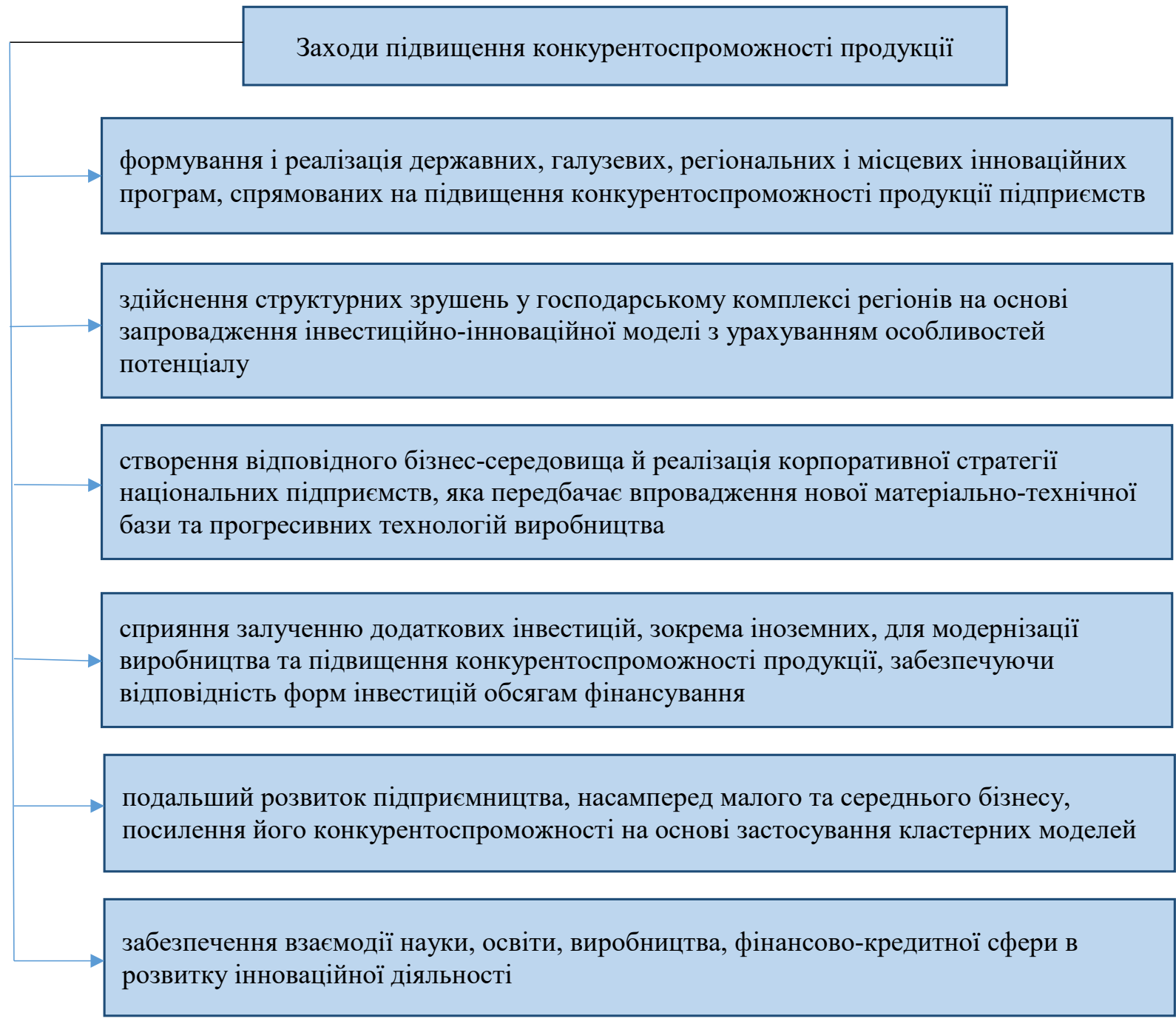

Рис. 3. Заходи підвищення конкурентоспроможності продукції ТДВ «Конотопм’ясо» 


\section{ВИСНОВКИ}

Отже, визначено залежність ефективності діяльності підприємства від вибору та використання інструментів, які допомагають розробити план стратегічних дій відповідно до наявних конкурентних переваг підприємства. Відповідним інстру- ментом виступає механізм, який пристосований до наявних умов господарювання. Такі розробки дозволяють керівникам підприємств моделювати варіанти можливих рішень відповідно до ситуацій, що виникають, за врахування інтересів і цілей підприємства.

\section{REFERENCES}

[1] Kovtun O. I. (2009) Stratehiiapidpryiemstva[Enterprisestrategy]. Lviv :Novyisvit-2000. [in Ukrainian]

[2] PiddubnaL. I. (2011) Mizhnarodnakonkurentospromozhnistpidpryiemstva: teoriiatamekhanizmzabezpechennia[Internationa lcompetitivenessoftheenterprise: theoryandmechanismofproviding], Kharkiv: VD "INZhEK". [in Ukrainian]

[3] Dolzhanskyil.Z., ZahornaT. O. (2006) Konkurentospromozhnistpidpryiemstva[Competitivenessoftheenterprise], Kyiv: Tsentrnavchalnoiliteratury. [inUkrainian]

[4] Sivachenko I.Yu., KozakYu.H. (2005) Upravlinniamizhnarodnoiukonkurentospromozhnistiupidpryiemstv [Managementofin ternationalcompetitivenessofenterprises], Kyiv: Tsentrnavchalnoiliteratury. [in Ukrainian]

\section{СПИСОК ВИКОРИСТАНОӤ ЛІТЕРАТУРИ}

[1] Ковтун О.І. Стратегія підприємства. Львів : Новий світ-2000, 2009. 276 с.

[2] Піддубна Л.І. Міжнародна конкурентоспроможність підприємства: теорія та механізм забезпечення. Харків : ВД «ІНЖЕК», 2011. $400 \mathrm{c}$.

[3] Должанський І.З., Загорна Т.О. Конкурентоспроможність підприємства. Київ : Центр навчальної літератури, 2006. $384 \mathrm{c}$.

[4] Сіваченко І.Ю., Козак Ю.Г. Управління міжнародною конкурентоспроможністю підприємств. Київ : Центр навчальної літератури, 2005. 491 с. 